\title{
Substance P provides neuroprotection in cerebellar granule cells through Akt and MAPK/Erk activation: Evidence for the involvement of the delayed rectifier potassium current
}

\author{
G. Amadoro $^{\text {a, },}$, M. Pieri ${ }^{\text {b,c, },}$, M.T. Ciotti ${ }^{\text {a }}$, I. Carunchio ${ }^{\text {b,c }}$, N. Canu ${ }^{\text {a,b }}$, \\ P. Calissano ${ }^{\mathrm{a}, \mathrm{b}}$, C. Zona ${ }^{\mathrm{b}, \mathrm{c}}$, C. Severini ${ }^{\mathrm{a}, *}$ \\ a Institute of Neurobiology and Molecular Medicine, CNR, Via del Fosso di Fiorano, 65, 00143 Rome, Italy \\ ' Department of Neuroscienze, University of Rome "Tor Vergata", Via Montpellier, 1-00133 Rome, Italy \\ ${ }^{\mathrm{c}}$ C.E.R.C. Fondazione S. Lucia, Via del Fosso di Fiorano, 65, 00143 Rome, Italy
}

Received 19 July 2006; received in revised form 9 January 2007; accepted 23 January 2007

\begin{abstract}
In the current study, we have evaluated the ability of substance P (SP) and other neurokinin 1 receptor (NK1) agonists to protect, in a dose- and time-dependent manner, primary cultures of rat cerebellar granule cells (CGCs) from serum and potassium deprivation-induced cell death (S-K5). We also established the presence of SP high affinity NK1 transcripts and the NK1 protein localization in the membrane of a sub-population of CGCs. Moreover, SP significantly and dose-dependently reduced the Akt 1/2 and Erk1/2 dephosphorylation induced by S-K5 conditions, as demonstrated by Western blot analysis. Surprisingly, in SP-treated CGCs caspase-3 activity was not inhibited, while the calpain-1 activity was moderately reduced. Corroborating this result, SP blocked calpain-mediated cleavage of tau protein, as demonstrated by the reduced appearance of a diagnostic fragment of $17 \mathrm{kDa}$ by Western blot analysis. In addition, SP induced a significant reduction of the delayed rectifier $\mathrm{K}^{+}$currents $\left(\mathrm{I}_{\mathrm{k}}\right)$ in about $42 \%$ of the patched neurons, when these were evoked with depolarizing potential steps. Taken together, the present results demonstrate that the activation of NK1 receptors expressed in CGCs promote the neuronal survival via pathways involving Akt and Erk activation and by inhibition of $I_{k}$ which can contribute to the neuroprotective effect of the peptide.
\end{abstract}

(C) 2007 Published by Elsevier Ltd.

Keywords: Substance P; Neuroprotection; Cerebellar granule cells; Tachykinin receptors

\section{Introduction}

Tachykinins (TKs) are a family of neuropeptides sharing a common C-terminal sequence essential for their biological activity. The mammalian TKs include substance $\mathrm{P}$ (SP), neurokinin A (NKA), and neurokinin B (NKB) that exert their effects by binding to three distinct types of receptors defined NK1, NK2, and NK3, respectively, that belong to the family of $\mathrm{G}$ protein-coupled receptors regulated phosphoinositide

\footnotetext{
* Correspondig author. Tel.: +3965017 03234; fax: +396501703311.

E-mail address: c.severini@inmm.cnr.it (C. Severini).

${ }^{1}$ These two authors equally contributed to this work.
}

pathway (Pennefather et al., 2004). TKs receptors are widely distributed in the central and peripheral nervous system of various species (Otsuka and Yoshioka, 1993; Pennefather et al., 2004). In the brain, TK receptors are implicated in the control of autonomic, affective and higher cerebral functions playing a very important role as neurotransmitters, neuromodulatory and neurotrophic agents (Severini et al., 2002). It has been recognized that TKs have a variety of effects in physiological and pathological conditions and there are evidences suggesting intrinsic excitatory properties of these neuropeptides (Raffa, 1998; Pieri et al., 2005). On the other hand SP, the most studied TK, was demonstrated to exert neurotrophic and neuroprotective activity both in vitro and in vivo and may exerts its 
action as non-specific growth factor for peripheral and central nervous tissues (Lallemend et al., 2003; Salthun-Lassalle et al., 2005). The importance of this neuroprotective effect may be relevant in neurodegenerative disorders such as in the neuropathology of Alzheimer's disease (Raffa, 1998).

In vitro cultures of newborn rat cerebellar granule cells (CGCs) represent one of the most widely used experimental model to study neuronal cell death because of the high degree of cellular homogeneity, allowing the study of the effect of substances that can modulate this process. CGCs survive and differentiate in vitro in the presence of depolarizing concentrations of $\mathrm{KCl}(25 \mathrm{mM})$ without additional need for neurotrophic factors (Gallo et al., 1990). The mechanism of action of $\mathrm{KCl}$ remains controversial so far, but, generally, it is believed that an increase in intracellular $\mathrm{Ca}^{2+}$ concentration (D'Mello et al., 1993; Galli et al., 1995) and mitogen-activated protein kinase (MAPK) activation (Rosen et al., 1994) induced by depolarization are involved. If the serum is removed and the concentration of $\mathrm{KCl}$ is kept below depolarizing levels (K5) the majority of CGCs die by an apoptotic process (D'Mello et al., 1993). Under these conditions, the neuronal death is initiated by the activation of caspases, mainly caspases-3 (Canu and Calissano, 2003) and other cysteine proteases, including calpain (Verdaguer et al., 2005).

In view of the finding reporting the protective effect exerted by SP in various biological systems and the clear evidence demonstrating the distribution of NK1 receptors in the rat cerebellum (Otsuka and Yoshioka, 1993), we investigated whether the presence of SP in CGCs can influence the regulation of the viability of these neurons. In summary, the present work was designed to explore: (1) the biological action exerted by SP in CGCs in serum and potassium withdrawal conditions; and (2) the biochemical and electrophysiological mechanism by which this action is conveyed.

\section{Materials and methods}

\subsection{Primary cultures of cerebellar granule cells}

The regional animal Ethics committee approved the experiments. Cultures enriched in granule neurons were obtained from dissociated cerebella of 8 days-old Wistar rats (P8) as previously described by Levi et al. (1984). Cells were plated in basal Eagle's medium (BME, Gibco, Milan, Italy) supplemented with $10 \%$ fetal calf serum (Gibco), $25 \mathrm{mM} \mathrm{KCl}, 2 \mathrm{mM}$ glutamine (Gibco) and $100 \mu \mathrm{g} / \mathrm{ml}$ gentamycin (Gibco) in 24-well clusters, (NUNC), previously coated with poly-L-Lysine. CGCs were plated at a constant density of $0.5 \times 10^{6}$ cells/ well in BME. After 6 days "in vitro" (DIV), extracellular $\mathrm{KCl}$ was lowered from 25 to $5 \mathrm{mM}$ for neuronal cell death. Cultured neurons were washed $(2 \times)$ with serum-free BME containing $5 \mathrm{mM} \mathrm{KCl}$ incubated in the same medium up to $72 \mathrm{~h}$ (D'Mello et al., 1993). Neuronal viability was assessed by counting the number of intact nuclei according to the method described by Volontè et al. (1994). The culture was removed and replaced with $0.5 \mathrm{ml}$ of a detergent containing lysing solution $(0.5 \%$ ethylhexadecyldimethylammonium bromide, $0.28 \%$ acetic acid, $0.5 \%$ Triton $\mathrm{X}-100,3 \mathrm{mM} \mathrm{NaCl}, 2 \mathrm{mM} \mathrm{MgCl}_{2}$, in PBS pH 7.4 diluted 1/10). After $2 \mathrm{~min}$, the cells were collected and the solution consisted of a uniform suspension of single, intact, viable nuclei that were then quantified by counting in hemocytometer. Broken or damaged nuclei were not included in the counts. Alternatively, CGCs were fixed in $4 \%$ paraformaldehyde and permeabilized with $0.2 \%$ Triton $\mathrm{X}-100$ in Tris $-\mathrm{HCl} 0.1 \mathrm{M} \mathrm{pH} 7.4$ for $5^{\prime}$ and then incubated with Hoechst $33258(0.25 \mu \mathrm{g} / \mathrm{ml})$ for $5 \mathrm{~min}$ at room temperature.
After washing with PBS, the percentage of shrunken and condensed nuclei was assessed.

\subsection{TK agonists and antagonist effect}

In order to verify the effect of NK1 receptor agonists, at 6 DIV CGCs were incubated for $12,24,48$ or $72 \mathrm{~h}$ with the peptides tested or with the peptides in presence of the antagonist or, to test the effect on neuronal cell death, simultaneously exposed to $\mathrm{KCl} 5 \mathrm{mM}$. Counting intact nuclei as previously described assessed cell viability.

\subsection{Data analysis}

Cell viability was estimated by counting intact nuclei and data were collected from different cell batches. Analyses of data from treated cultures and the corresponding control condition were performed by one-way analysis of variance (ANOVA) for repeated measures followed by Dunnett's test or by Tukey's test for multiple comparisons when necessary. Data are reported as mean \pm SEM, $n$ being the number of independent experiments. The significance level was set at $P<0.05(*)$ and $P<0.01(* *)$.

\subsection{Immunocytochemistry}

CGCs were stained for $1 \mathrm{~h}$ at $4{ }^{\circ} \mathrm{C}$ using a rabbit polyclonal anti-NK1 receptor antibody 1:400 in PBS (NB 300-101, Novus Biologicals). Neurons were then washed in PBS and incubated with a goat anti-rabbit rhodamine-conjugated secondary antibody (Sigma) for $30 \mathrm{~min}$ at room temperature. Cells were fixed in $4 \%(\mathrm{w} / \mathrm{v}$ in PBS) paraformaldehyde for $10 \mathrm{~min}$ at room temperature on immunofluorescence-labeled coverslips and then incubated with Hoechst $33258(0.25 \mu \mathrm{g} / \mathrm{ml})$ for $5 \mathrm{~min}$ at room temperature. CGCs were then visualized by a Laica fluorescent photomicroscope and scored by counting 12 microscopic fields per coverslip in 2 coverslips from 4 experiments. Controls to assess primary antibody specificity were performed by including omission of the primary antibody.

\subsection{RT-PCR studies}

Total RNA was isolated from 6 DIV cultures of postnatal cerebellar granule neurons by Comczynski-Sacchi method (Chomczynski and Sacchi, 1987). RNA concentration was measured by spectrophotometry $(\lambda=260 / 280 \mathrm{nM})$. One microgram of total RNA was reverse transcripted using reverse transcriptase, oligo-dT primers and dNTP mix (Promega) for $1 \mathrm{~h}$ at $37^{\circ} \mathrm{C}$. Two microlitres of solution resulting from the RT-reaction were used as template and added to $50 \mu \mathrm{l}$ of PCR reaction mixture containing: $0.2 \mu \mathrm{M}$ of forward (5'GATAACGTCCTTCCTATGGAC-3') and reverse (5'-ATGTACCGGTAGTA GGTGGGA- ${ }^{\prime}$ ) specific primers for NK1 synthesized by Invitrogen (Life Technologies), $0.2 \mathrm{mM}$ of each dNTP, $1.5 \mathrm{mM}$ of $\mathrm{MgCl}_{2}$ and $0.5 \mu \mathrm{l}$ of TaqPolymerase (Promega). After denaturation $\left(94^{\circ} \mathrm{C}\right.$ for $\left.3 \mathrm{~min}\right)$, amplifications were carried out for 30 cycles of $94{ }^{\circ} \mathrm{C} / 15 \mathrm{~s}, 56{ }^{\circ} \mathrm{C} / 20 \mathrm{~s}$ and $72{ }^{\circ} \mathrm{C} / 30 \mathrm{~s}$. Ten microlitres of each PCR product were estimated by comparison with the migration of a standard molecular weight marker series. Negative controls were realized by omitting the enzyme in the reverse transcriptase reaction step.

\subsection{Caspase bioassay}

Caspase-3 activity was measured as previously described (Canu et al., 2000). A total of 500,000 CGCs were washed once with PBS $1 \times$ and lysed in $100 \mu \mathrm{l}$ of buffer A (10 mM HEPES pH 7.4, $42 \mathrm{mM} \mathrm{KCl}, 5 \mathrm{mM} \mathrm{MgCl}_{2}$, $1 \mathrm{mM}$ DTT, and $1 \mathrm{mM}$ PMSF, 0.5\% 3-(3-cholamidopropyl)dimethylammonio-1-propanesulfonic acid (CHAPS), and $1 \mu \mathrm{g} / \mathrm{ml}$ leupeptin). The lysates $(25 \mu \mathrm{l})$ were combined with $75 \mu \mathrm{M}$ of buffer B (25 mM HEPES, $1 \mathrm{mM}$ EDTA, $0.1 \%$ CHAPS, $10 \%$ sucrose, and $2 \mathrm{mM}$ DTT pH 7.5) containing $30 \mu \mathrm{M}$ Ac-DEVD-MCA and incubated for $20 \mathrm{~min}$ at room temperature. The fluorescence was measured at an excitation of $380 \mathrm{nM}$ and an emission of $460 \mathrm{~mm}$ wavelength, using Packard Fluorocount microplate reader (Packard Bioscience Company). 


\subsection{Western blotting}

For whole-cell lysates, the culture medium was discarded, the neurons washed twice with ice-cold phosphate-buffered saline (PBS), and lysed in lysis buffer (1\% NP40, $50 \mathrm{mM}$ Tris- $\mathrm{HCl}(\mathrm{pH} 8), 150 \mathrm{mM} \mathrm{NaCl}, 10 \%$ glycerol, $0.5 \mathrm{M} \mathrm{Na}_{2}$ EDTA, 0.5 M EGTA, $50 \mathrm{mM} \mathrm{NaF}, 2.5 \mathrm{mM}$ sodium pyrophosphate, $1 \mathrm{mM}$ beta-glycerophosphate, $1 \mathrm{mM} \mathrm{Na}_{3} \mathrm{VO}_{4}, 1 \mu \mathrm{g} / \mathrm{ml}$ leupeptin and $1 \times$ protease inhibitor mixture). Protein concentration was measured using a Biorad DC protein assay kit (Bio-Rad), and equivalent amounts of protein were mixed with $1 \times$ SDS-reducing sample buffer. Following heating at $95{ }^{\circ} \mathrm{C}$ for $5 \mathrm{~min}$, proteins were subjected to SDS-polyacrylamide gel electrophoresis (PAGE) and transferred electrophoretically to polyvinylidene difluoride membrane (Bio-Rad). After staining with Ponceau S to verify uniformity of protein loads/transfer, the membranes were analyzed for immunoreactivity. Incubation with primary antibodies was performed overnight at $4{ }^{\circ} \mathrm{C}$ (mouse tau-1, Boehringer Mannheim, Germany 1:5000; rabbit Akt 1/ 2/p-Akt and Erk1/2/p-Erk, Cell Signaling 1:1000; rabbit NK1 receptor, Novus Biologicals, 1:1000; rabbit cleaved caspase 3 (Asp175) Cell Signaling 1:1000; rabbit calpain-1 domain IV C-terminal, Sigma 1:1000; mouse PARP-1, Sigma 1:1000; mouse $\beta$-actin Sigma 1:10,000). Incubation with secondary antibodies peroxidase-coupled anti-mouse/rabbit was performed for $1 \mathrm{~h}$ at room temperature. Immunoreactivity was developed by enhanced chemiluminescence (ECL system; Amersham, Arlington Heights, IL) and visualized by autoradiography.

For analysis of the Western blotting data, densitometric analysis was performed using Scan Analysis software.

\subsection{Electrophysiological recordings}

Whole cell patch-clamp recordings were made from CGCs 8-10 DIV in culture. The recording electrodes were pulled from borosilicate glass with an outer diameter of $1.2 \mathrm{~mm}$ and had open tip resistances of 4-5 M 2 . To record the voltage-dependent $\mathrm{K}^{+}$currents the internal solution for filling electrodes consisted of $120 \mathrm{mM} \mathrm{KCl}, 5 \mathrm{mM}$ EGTA, $0.24 \mathrm{mM} \mathrm{CaCl}_{2}, 10 \mathrm{mM}$ HEPES, $30 \mathrm{mM}$ D-glucose, $2 \mathrm{mM}$ ATP, $1 \mathrm{mM} \mathrm{MgCl}$, pH 7.3 with $\mathrm{KOH}$. The standard extracellular solution consisted of $120 \mathrm{mM} \mathrm{NaCl}, 3 \mathrm{mM} \mathrm{KCl}$, $2 \mathrm{mM} \mathrm{MgCl}_{2}, 2 \mathrm{mM} \mathrm{CaCl}_{2}$, and $10 \mathrm{mM}$ HEPES, $20 \mathrm{mM}$ D-glucose, $\mathrm{pH} 7.4$ with $\mathrm{NaOH}$. Tetrodotoxin (TTX, $1 \mu \mathrm{M})$ and $\mathrm{CdCl}_{2}(0.2 \mathrm{mM})$ were added to the extracellular medium to block sodium and calcium currents, respectively. Recordings were obtained with an Axopatch-200B amplifier (Axon Instruments, USA). Holding potentials and stimulation templates were done using a pClamp 8 software (Axon Instruments, USA). Experiments were performed at room temperature $\left(22-24{ }^{\circ} \mathrm{C}\right)$. After the establishment of a gigaseal, the pipette resistance and capacitance were compensated electronically. Current signals were digitized at $50 \mathrm{KHz}$ and filtered at $10 \mathrm{KHz}$.

Unless otherwise stated, the compounds to be tested were added to the perfusion solution. SP and antagonist were applied by multi-barrel pipette gravity perfusion system controlled by electronic valves positioned near the soma of the recorded neuron using a fast perfusion system (SF-77B Warner Ins., Hamden, CT, USA).

Statistical analyses were performed using SPSS 11.0.0 for Windows (SPSS Inc., USA). All results are expressed as mean \pm S.D., with $n$ the number of tested cells. The significance of the effect was performed by one-way analysis of variance (ANOVA) followed by paired Student's $t$-test. The significance level was set to 0.05 .

\subsection{Chemicals}

SP, $\left[\operatorname{Sar}^{9}, \operatorname{Met}\left(\mathrm{O}_{2}\right)^{11}\right]$ SP were from Neosystem, Strasbourg, France. Physalaemin was from Primm, Milan, Italy. NKA and NKB were from Bachem, Bubendorf, Switzerland. SR 140,333 was provided by Sanofi-Synthelabo Ricerche (Montpellier, France) and tetrodotoxin (TTX) was from Alomone (Jerusalem, Israel). The other reagents were from Sigma. Stock solutions of the peptides $(1-5 \mathrm{mM})$ were made, according to their solubility, either in $80 \%$ DMSO or in ethanol, stored at $4{ }^{\circ} \mathrm{C}$, and then diluted in water just before use.

\section{Results}

\subsection{Action of NK1 agonists on neuronal cell death}

As previously reported, when switched from a culture medium containing high $\mathrm{K}^{+}(25 \mathrm{mM})$ to one containing a low but more physiological $\mathrm{K}^{+}$concentration $(5 \mathrm{mM})$, CGCs degenerate and die (D'Mello et al., 1993). In view of the reported neuroprotective action of SP, we tested the effect of several NK1 agonists in this model of neuronal cell death. Besides $\mathrm{SP}$, the synthetic peptide $\left[\operatorname{Sar} 9, \operatorname{Met}\left(\mathrm{O}_{2}\right)^{11}\right] \mathrm{SP}$ and the amphibian NK1 selective peptide physalaemin (PHYS) were also used. CGCs, cultured in K25 for 6 DIV were further incubated for $48 \mathrm{~h}$ in $\mathrm{K} 5$ and in the presence of the agonists. As shown in Fig. 1A, SP, $\left[\mathrm{Sar}^{9}, \operatorname{Met}\left(\mathrm{O}_{2}\right)^{11}\right] \mathrm{SP}$ and PHYS exerted a significant effect on neuronal death compared to parallel control cells cultured in the same condition. On the contrary, no effect was observed using NKA or NKB at concentrations up to $1 \mu \mathrm{M}$ (data not shown). Incubation with $200 \mathrm{nM} \mathrm{SP},\left[\operatorname{Sar}^{9}, \operatorname{Met}\left(\mathrm{O}_{2}\right)^{11}\right] \mathrm{SP}$ or PHYS, induced a $36.1 \%, 36.4 \%, 35.1 \%$, increase in cell viability, respectively. Reported data were also confirmed by cell viability quantification by Hoechst staining, indicating the same percentage obtained counting intact nuclei (data not shown). In order to assess specificity of action, CGCs were incubated with SP in the presence of the selective NK1 antagonist SR 140,333 at different concentrations. We found that SR 140,333 antagonized SP activity at concentrations ranging between $5 \mathrm{nM}$ and $25 \mathrm{nM}$. SP activity was significantly reduced by $10 \mathrm{nM}$ antagonist (from 78.3 to $48.5 \%$ of cell viability) and completely abolished by $25 \mathrm{nM}$. The lack of action of the antagonist itself on neuronal viability ruled out any potential non-specific toxic effect of the drug (data not shown).

The same effect was observed incubating CGCs with $\left[\operatorname{Sar}^{9}, \operatorname{Met}\left(\mathrm{O}_{2}\right)^{11}\right]$ SP or PHYS $(200 \mathrm{nM})$ in the presence of the antagonist (data not shown).

In order to assess the effect of the same peptides on healthy neurons, equivalent experiments were ruled out in K25 conditions. As shown in Fig. 1A, neither SP nor the antagonist itself affected survival of CGCs, as well as the incubation with [Sar ${ }^{9}$, $\left.\operatorname{Met}\left(\mathrm{O}_{2}\right)^{11}\right] \mathrm{SP}$ or PHYS at different doses (data not shown).

Morphological analysis, by phase-contrast microscopy, indicated that in low $\mathrm{K}^{+}$conditions CGCs resulted severely damaged and showed morphological alterations associated with apoptosis displaying severe neuronal soma shrinkage and axonal retraction. On the contrary, CGCs incubated with NK1 receptor agonists showed neurites as intact as in control neurons (Fig. 1B). Resorting to SP as prototype, time- and dose-dependent response effects were also studied. Incubation of CGCs before death induction with $200 \mathrm{nM}$ SP for different times indicated that the neuroprotective effect began after an incubation of $12 \mathrm{~h}(8.6 \%)$, while a $21.4 \%$ effect was obtained after $24 \mathrm{~h}$, a maximal action after $48 \mathrm{~h}(36.1 \%)$ and $72 \mathrm{~h}$ (35.8\%) (Fig. 2A). Accordingly, a dose-response curve was carried out following $48 \mathrm{~h}$ incubation. In these conditions, incubation with 50,100, 200 and $500 \mathrm{nM}$ SP caused a $18.8 \%$, $32.1 \%, 36.6$ and $16.8 \%$ increase in cell viability, respectively (Fig. 2B). Dose-response curves obtained with the other NK1 

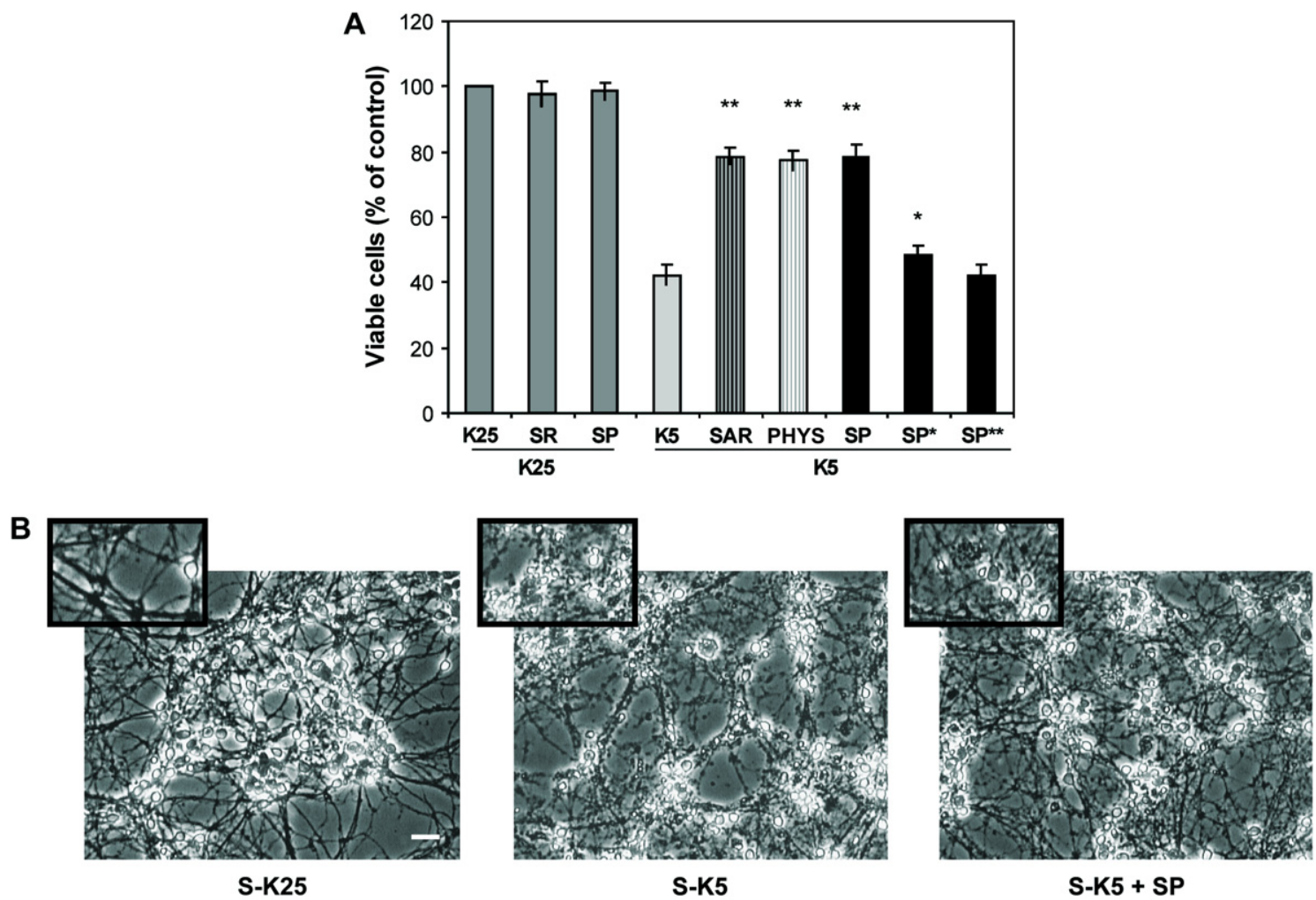

Fig. 1. Effect of NK1 receptor agonists on CGCs viability. (A) At 6 DIV extracellular $\mathrm{KCl}$ was lowered from 25 (K25) to $5 \mathrm{mM}$ (K5) for neuronal cell death induction and simultaneously neurons $\left(0.5 \times 10^{6}\right.$ cells/well) were treated with the agonists tested at $200 \mathrm{nM}$ and incubated for $48 \mathrm{~h}$. SP, [Sar $\left.{ }^{9}, \mathrm{Met}\left(\mathrm{O}_{2}\right)^{11}\right] \mathrm{SP}(\mathrm{SAR})$ and fisalaemin (PHYS) significantly protected CGCs as compared to K5 value. Treatment with SR 140,333, a specific NK1 antagonist, induced a considerable inhibitory effect on the SP-promoted neuroprotection at the concentration of $10 \mathrm{nM}(\mathrm{SP} *)$ and $25 \mathrm{nM}$ (SP**). No effect was observed incubating CGCs for $48 \mathrm{~h}$ with SP $(200 \mathrm{nM})$ and with the antagonist alone (SR, $25 \mathrm{nM})$ in K25 conditions. (B) Representative phase-contrast images of CGCs in a control sample (K25), in an apoptotic sample (K5) and in a K5 culture exposed to SP $(200 \mathrm{nM})$ treatment. Scale bar: $12 \mu \mathrm{m}(3 \times$ magnification in each panel). Data represent means $( \pm \mathrm{SEM})$ from at least 6 duplicate experiments. Statistically significant differences were calculated by one-way analysis of variance (ANOVA) for repeated measures followed by Dunnett's test, analyzing data from treated cultures and corresponding control (K5). $\left({ }^{*} p<0.05 ; * * p<0.01\right)$.
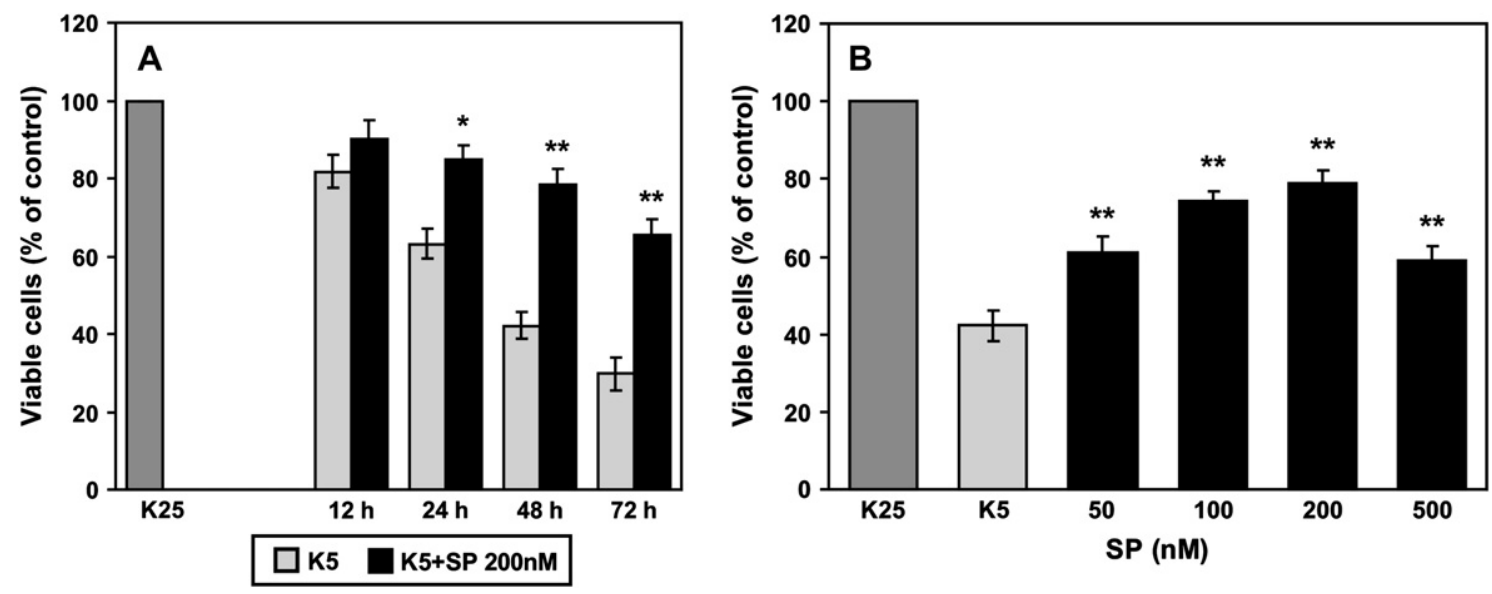

Fig. 2. Effect of SP on CGCs viability. (A) At 6 DIV extracellular $\mathrm{KCl}$ was lowered from 25 (K25) to $5 \mathrm{mM}$ (K5) for neuronal cell death induction and simultaneously neurons $\left(0.5 \times 10^{6}\right.$ cells/well $)$ were treated with SP $200 \mathrm{nM}$ and incubated for different times. The neuroprotective effect of SP was significant after $24 \mathrm{~h}$ and the maximal effect was obtained after $48 \mathrm{~h}$ and $72 \mathrm{~h}$ incubation time, as compared to the corresponding K5 value. (B) Effect of different doses of SP on CGCs viability following $48 \mathrm{~h}$ incubation in S-K5 medium. The highest neuroprotective effect was evident at $200 \mathrm{nM}$ SP. Data represent means ( \pm SEM) from at least 6 duplicate experiments. Statistically significant differences were calculated by one-way analysis of variance (ANOVA) for repeated measures followed by Dunnett's test, analyzing data from treated cultures and corresponding control (K5). $(* p<0.05 ; * * p<0.01)$. 
preferring peptides showed similar dose-response activities (data not shown). Thus, the concentration of $200 \mathrm{nM}$ was used in all subsequent experiments.

\subsection{Detection of NKI receptor in CGCs}

Since the presence of TK receptors in CGCs has been reported only for NK2 and NK3 receptors (Pieri et al., 2005), we utilized amplification by RT-PCR using NK1-specific primers-pairs on cDNA by total RT-RNA extracted from CGCs in order to demonstrate the presence of NK1 receptor in these neurons. The results obtained revealed PCR products of the predicted size (Fig. 3A). No detectable amplification was observed using control samples. NK1 receptor presence was also confirmed by Western blot analysis and by immunocytochemistry using a specific polyclonal antibody directed against the receptor. As shown in Fig. 3B, CGCs at 6 DIV expressed NK1 receptor protein $(53 \mathrm{kDa})$ and, as shown in Fig. 3C, about $47 \%( \pm 5 \%, n=96$ fields, see Section 2$)$ were positive for NK1 receptor antibody, showing the typical punctate distribution of the receptors. No staining was detectable when the secondary antibody alone was used.

\subsection{Neuroprotection by SP was Akt and MAPK/Erk 1/2 dependent}

It is well established that phosphorylation of both serine/ threonine protein kinase Akt and of MAPK/Erk1/2 is associated with CGCs survival (Gunn-Moore et al., 1997; Zhu et al., 2004) and that the relative basal levels are down-regulated when CGCs are switched in medium containing $5 \mathrm{mM}$ $\mathrm{KCl}$ (Chaib-Oukadour et al., 2004). As previously reported, the MAPK/Erk 1/2 pathways activation is involved in the anti-apoptotic mechanism of action of SP observed in neuronal cells (Lallemend et al., 2003). We have examined whether, in CGCs, the neuroprotective effect of SP modified such kinases involved in this paradigm of neuronal death. To investigate this hypothesis, CGNs at 6 DIV were treated for $48 \mathrm{~h}$ with S$\mathrm{K} 25$, K5 or K5 medium containing SP $(100-200 \mathrm{nM})$ in the absence or presence of the selective NK1 antagonist SR 140,333 at different doses. Lysates from CGCs were subjected to Western blot analysis using antibodies specific for phosphorylated (activated) Akt and Erk1/2. The same blot was stripped and reprobed with antibodies against total Akt1/2 and Erk1/2 levels. Quantitative analysis of Akt and Erk1/2 phosphorylation of different experiments was determined by densitometry analysis and the densitometric values from phosphorylated Akt and Erk1/2 were normalized using total Akt1/2 and Erk1/2 as internal controls. The ratio of the band intensities was calculated considering the values found in $\mathrm{K} 25$ treated cells as 1 . As shown in Fig. 4A, following $48 \mathrm{~h}$ incubation, SP dose-dependently prevented the K5-induced dephosphorylation of Akt. This effect was specific since SR 140,333 (10-25 nM) dosedependently antagonized the SP effect on Akt phosphorylation. Additionally, the lack of action of the antagonist itself on phosphorylation ruled out any potential non-specific toxic effect of the drug.
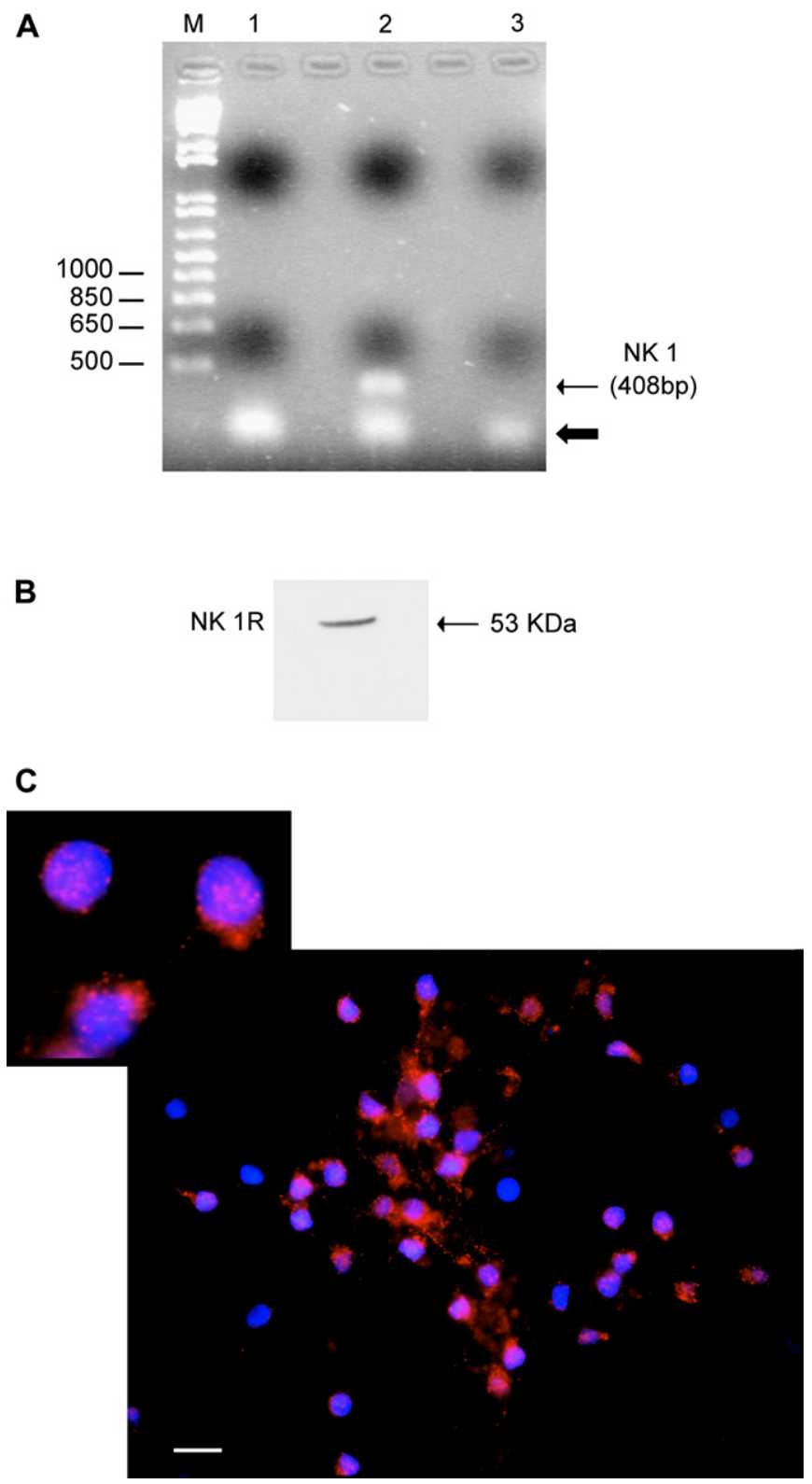

Fig. 3. (A) RT-PCR products of cDNA from rat CGCs 8 days old in culture (DIV) stained with ethidium bromide using NK1 specific primers. A DNA band of the predict size of $408 \mathrm{bp}$ (NK1) was observed in the lane 2 (thin arrow). Lane $\mathrm{M}$ represents the molecular weight marker. Lane 1 (omission of reverse trascriptase) and 3 (oligo forward) contain the negative controls (thick arrow indicates primers). Enzymatic digestion of RT-PCR products produced fragments of the expected size, suggesting accurate amplification of target transcripts. (B) Western blot analysis. Using a rabbit anti-NK1 receptor polyclonal antibody (NB 300-101, Novus Biologicals) CGCs at 6 DIV revealed the expression of a $53 \mathrm{kDa}$ protein corresponding to NK1 receptor. (C) Representative immunofluorescence photomicrograph. The immunofluorescence image shows CGNs stained with the same antibody (NB 300-101, Novus Biologicals) at 6 DIV (red). Nuclei were stained with Hoechst (blue). Scale bar: $12 \mu \mathrm{m}$ ( $3 \times$ magnification).

Comparable results were obtained on Erk1/2 phosphorylation although the effect of the antagonist against SP activity resulted statistically significant only at the highest dose (Fig. 4B). To confirm the involvement of MAPK-Erk 1/2 pathways in the mechanism of action of SP, CGCs were treated 

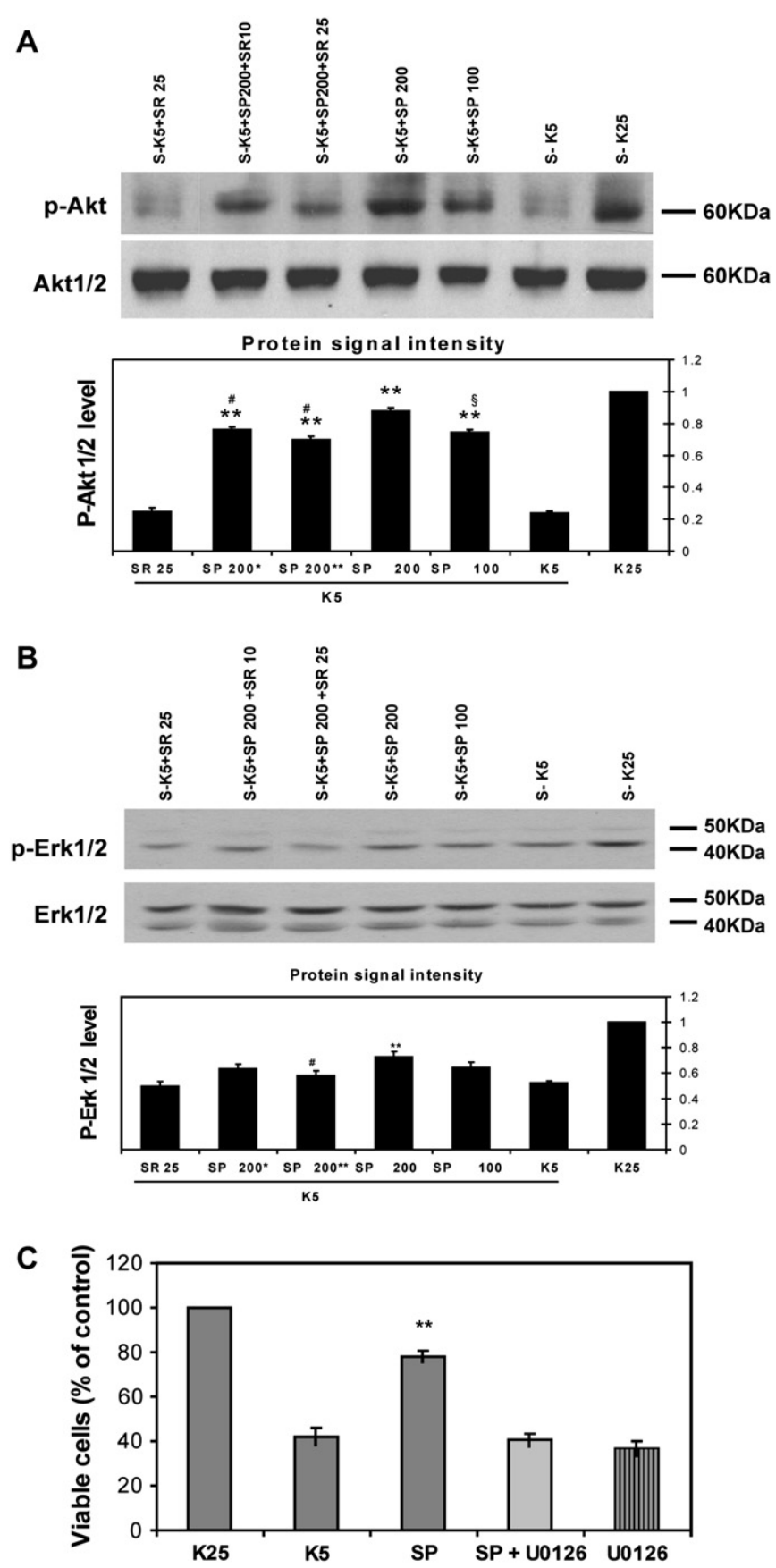

Fig. 4. Action of SP on the Akt and Erk 1/2 phosphorylation during the CGCs death induced by potassium and serum deprivation. At 6 DIV, CGCs were treated for $48 \mathrm{~h}$ in S-K25 (control) or switched in S-K5 alone or in the presence of SP at different concentrations (100 and $200 \mathrm{nM})$. The action of the NK1 receptor antagonist SR140,333 (SR) was evaluated treating the CGCs with the antagonist at different concentrations (10 and $25 \mathrm{nM})$ alone, or in the presence of SP $(200 \mathrm{nM})$. Cells were lysated and processed for immunoblotting. (A) Western blot analysis using an antibody specific for the phosphorylated (active) Akt (p-Akt) (upper panel). The same blot was stripped and reprobed with an antibody against total Akt $1 / 2$ to confirm that similar amounts of proteins were present in each lane (lower panel). (B) Western blot analysis using an antibody specific for the phosphorylated (active) Erk 1/2. The same blot was stripped and reprobed with an antibody against total Erk1/2 (Erk) (lower panel). Quantitative analysis of Akt and Erk1/2 phosphorylation is depicted below the respective blots and was determined by band densitometry analysis. The densitometric values from phosphorylated Akt and Erk1/2 were normalized using total Akt1/2 and Erk1/2 as internal controls. The ratio with the specific MEK inhibitor 1-4-Diamino-2-3-dicyano1-4-bis(2-aminophynyltio)butadiene (UO126) at a final concentration of $10 \mu \mathrm{M}$. UO126 was added at 6 DIV $1 \mathrm{~h}$ before or simultaneously the induction of apoptosis. As the inhibitor showed the same effect in all cases, the first protocol described was used for further experiments. As shown in Fig. 4C, UO126 completely prevented the neuroprotective effect exerted by SP, while only weak effect was observed on neuronal viability treating CGCs with UO126 alone. In addition, $10 \mu \mathrm{M}$ UO126 blocked the increased Erk1/2 phosphorylation induced by SP, while treatment with MEK inhibitor alone weakly reduced the intensity of pErk immunolabeling, as compared to K5 culture values.

\subsection{SP protected K5-injured CGCS without affecting caspase-3 activity}

To investigate whether the neuroprotective effect of SP is associated with down-regulation of a caspase-dependent apoptotic process, we have quantified the enzymatic activity of caspase- 3 by measuring the fluorescence emitted after the cleavage of the substrate Ac-DEVD-MCA in S-K5 CGCs incubated, up to $48 \mathrm{~h}$, with or without NK1 agonists. SP at $200 \mathrm{nM}$ concentration did not inhibit caspase- 3 activity, which increased following $\mathrm{K}^{+}$ and serum deprivation, reaching similar levels of activation both in SP treated and untreated CGCs (Fig. 5A). Similar results were obtained using $\left[\mathrm{Sar} 9, \operatorname{Met}\left(\mathrm{O}_{2}\right)^{11}\right] \mathrm{SP}$ or PHYS $200 \mathrm{nM}$ (data not shown).

To confirm the result, CGCs were treated with $10 \mu \mathrm{M}$ ZVAD-fmk, a specific caspase(s) inhibitor, routinely used in this model of neuronal death (Armstrong et al., 1997). ZVADfmk was added simultaneously the induction of apoptosis and the activity of caspase- 3 measured after $12 \mathrm{~h}$ incubation. Treatment with ZVAD-fmk completely blocked the activation of caspase-3 (data not shown).

Furthermore, we confirmed the results above described analyzing the appearance of the caspase 3 active fragment and the proteolysis of PARP-1, an enzyme involved in DNA repair, known to be its specific substrate (Lazebnik et al., 1994). To this aim, we performed Western blotting analysis using an antibody that recognizes $17 / 19 \mathrm{kDa}$ caspase 3 active fragment (Asp 175) and mAb PARP-1, an antibody that specifically recognizes the $85 \mathrm{kDa}$ fragment released by caspase-3-mediated cleavage of PARP-1. Both in SP-treated and untreated S-K5 CGNs, was detected the caspase 3 active fragment as well as the $85 \mathrm{kDa}$ PARP-1 fragment (Fig. 5B).

of the band intensities was calculated considering the values found in K25 treated cells as 1. (C) Effect of UO126. At 6 DIV extracellular $\mathrm{KCl}$ was lowered from 25 (K25) to $5 \mathrm{mM}$ (K5) for neuronal cell death induction and simultaneously neurons were treated with SP $200 \mathrm{nM}$ and incubated for $48 \mathrm{~h}$. Treatment with UO126, a specific MAPK kinases inhibitor, induced a complete inhibitory effect on the SP-promoted neuroprotection at the concentration of $10 \mu$ M. Data represent means $( \pm$ SEM) from 3 duplicate experiments. Statistically significant differences were calculated by one-way analysis of variance (ANOVA) for repeated measures followed by Tukey's test for multiple comparisons. $\left({ }^{*} p<0.05 ;{ }^{* *} p<0.01\right.$ versus $\mathrm{K} 5 ; \# p<0.05$ versus SP200; $\S p<0.01$ versus SP200). 


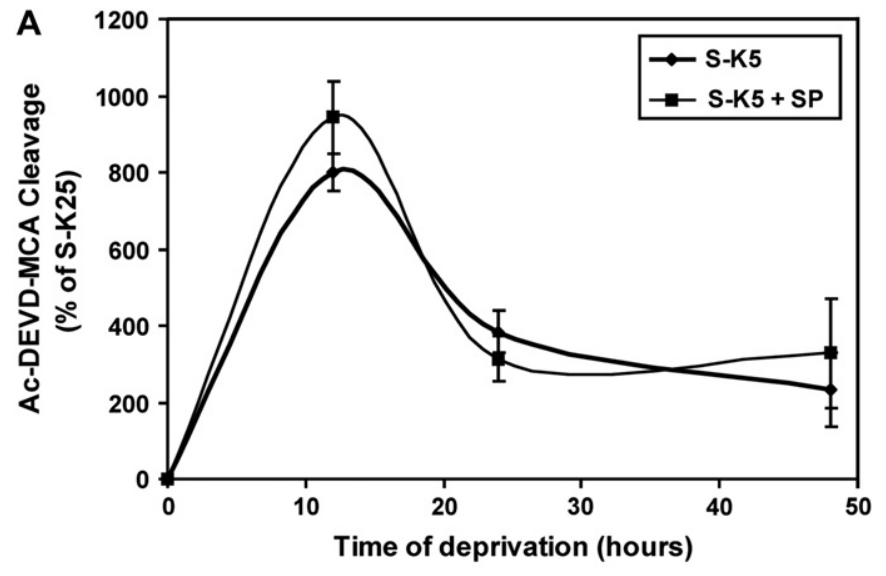

B

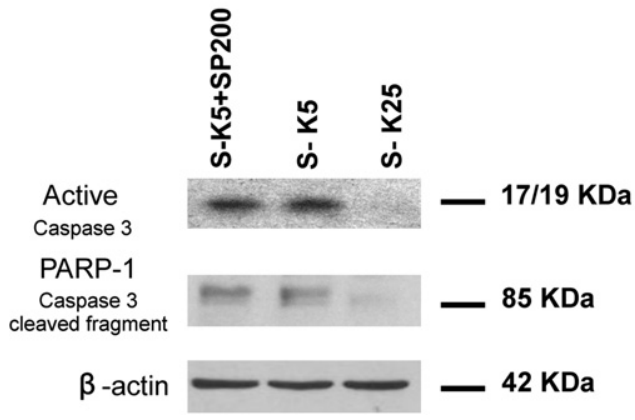

Fig. 5. Action of SP on the caspase-3 activity during the CGCs death induced by potassium and serum deprivation. (A) At 6 DIV, CGCs were maintained for up to $48 \mathrm{~h}$ in S-K25 or subjected to S-K5 alone or in the presence of SP at $200 \mathrm{nM}$. After 12, 24 and $48 \mathrm{~h}$, caspase- 3 activity was measured by monitoring the fluorescent product of the cleavage of Ac-DEVD-MCA by CGCs lysates. Accumulation of MCA was assayed fluorometrically after $20 \mathrm{~min}$ at room temperature. Data are reported as the percentage of the rate of cleavage in S-K25 extracts $(100 \%)$. Data represent means $( \pm$ SEM) from 3 duplicate experiments. (B) Western blot analysis. Equal amounts of whole-cell extracts were analyzed, following $48 \mathrm{~h}$ incubation, using an antibody that specifically recognizes the $17 / 19 \mathrm{kDa}$ caspase 3 active fragment (Asp 175) and mAb PARP-1 that specifically recognizes the $85 \mathrm{kDa}$ fragment released by caspase-3-mediated cleavage of PARP-1. $\beta$-actin immunoblot was used as loading control.

\subsection{SP protected K5-injured CGCs through inhibition of calpain-1}

Calpain-1 is another enzyme known to be activated in the same apoptotic conditions. To assess calpain-1 activity, we performed Western blotting analysis using an antibody that recognized $58 \mathrm{kDa}$ active form of calpain-1. As shown in Fig. 6A, active calpain levels were moderately but significantly reduced by treatment with SP 200 nM compared with K5 untreated controls. In addition, we confirmed the results previously described analyzing the proteolysis of tau, known to be a specific calpain1 substrate. We performed Western blotting analysis after $48 \mathrm{~h}$ treatment, using tau-1 antibody (P-189-202 aa) recognizing the $17 \mathrm{kDa}$ fragment, typically released by calpain- 1 during $\mathrm{K}^{+}$and serum deprivation in CGCs (Canu et al., 1998). As shown in Fig. 6B, SP was able, dose-dependently, to reduce the appearance of such diagnostic $17 \mathrm{kDa}$ fragment. This effect was specific since SR 140,333 (10-25 nM) dose-dependently antagonized the SP effect, although the effect was statistically significant only with the highest dose. Additionally, the lack of action of the antagonist itself on $17 \mathrm{kDa}$ fragment appearance ruled out any potential non-specific toxic effect of the drug. Quantitative analysis of active calpain-1 and of $17 \mathrm{kDa}$ fragment appearance was determined by densitometry analysis of different experiments and the ratio of the band intensities was calculated considering the values found in K25 treated cells as 1 .

\subsection{Effect of SP on transient and delayed outward $K^{+}$currents}

Recent evidences strongly suggest that $\mathrm{K}^{+}$-channel-mediated signals play important roles in regulation of apoptosis (Yu, 2003; Shieh et al., 2000). In addition, it has been reported that apoptosis of CGCs was associated with an enhancement of outward $\mathrm{K}^{+}$current induced by serum and potassium deprivation $(\mathrm{Hu}$ et al., 2005). In order to investigate whether neuroprotective effect of SP is associated with a modulation of voltage-dependent $\mathrm{K}^{+}$currents, we performed electrophysiological experiments to investigate whether SP application was able to modulate these currents in CGCs in culture. When voltage-activated $\mathrm{Na}^{+}$and $\mathrm{Ca}^{2+}$ currents were blocked by bath application of TTX and $\mathrm{Cd}^{2+}$, depolarizing commands from $-60 \mathrm{mV}$ elicited in granule cells 8-10 days old in culture, a time- and voltage-dependent outward $\mathrm{K}^{+}$current that rapidly reached a peak and then decayed towards a steady level (Fig. 7A). The two components of the voltage-dependent outward responses differed in their sensitivity to the extracellular application of 4AP and TEA. The component most sensitive to 4AP was the early, transient one; by contrast the slow, delayed component of the outward response was reduced by TEA, indicating then that two components were the fast transient $\left(\mathrm{I}_{\mathrm{A}}\right)$ and the delayed outward $\left(\mathrm{I}_{\mathrm{K}}\right) \mathrm{K}^{+}$currents (not shown, Zona et al., 1993). Application of SP (200 nM, 15$20 \mathrm{~s}$ ) did not significantly affect the peak of the transient outward current in all the patched cells $(n=48)$ but markedly decreased the delayed component in about $42 \%$ of the patched cells (Fig. 7). In these neurons, the amplitude of the outward currents evoked by a depolarization step to $+40 \mathrm{mV}$ from a holding potential of $-60 \mathrm{mV}$ significantly decreased (15.9 \pm 6.5 ; mean \pm S.D.; $n=20 ; p<0.05$; Fig. 7D). The decrease of this late component was reversible only in a few cells and never complete, even after 10-12 min of control solution perfusion (not shown).

\section{Discussion}

Some major findings emerged from this study: (a) NK1 receptors are present in approximately half of the entire population of cultured CGCs; (b) SP and other NK1 receptor agonists protect CGCs from neuronal cell death induced by serum and $\mathrm{K}^{+}$deprivation; (c) the neuroprotective effect exerted by SP is mediated by Akt and MAPK/Erk 1/2 activation; and (d) the delayed rectifier potassium current are modulated by SP.

Molecular, biochemical, and immunohistochemical data have pointed out that TK receptors are widely distributed in both the central and peripheral nervous system (Otsuka and 
A

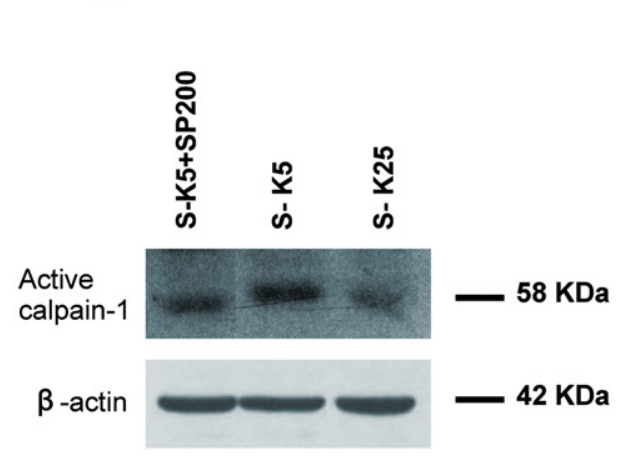

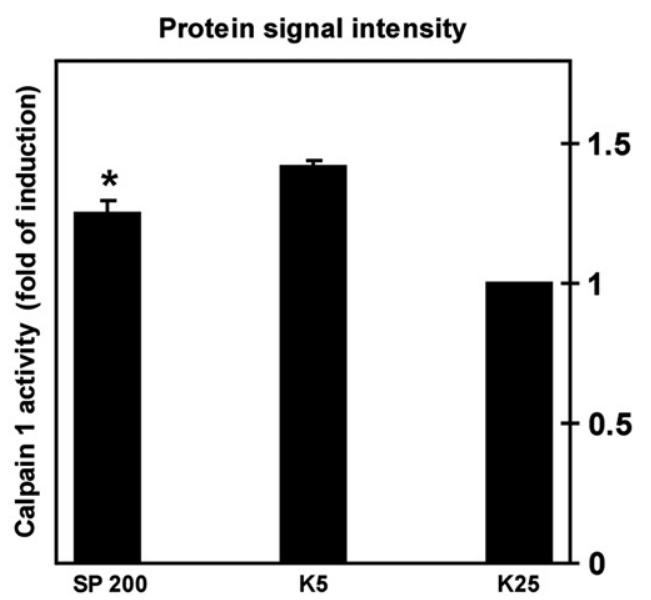

B
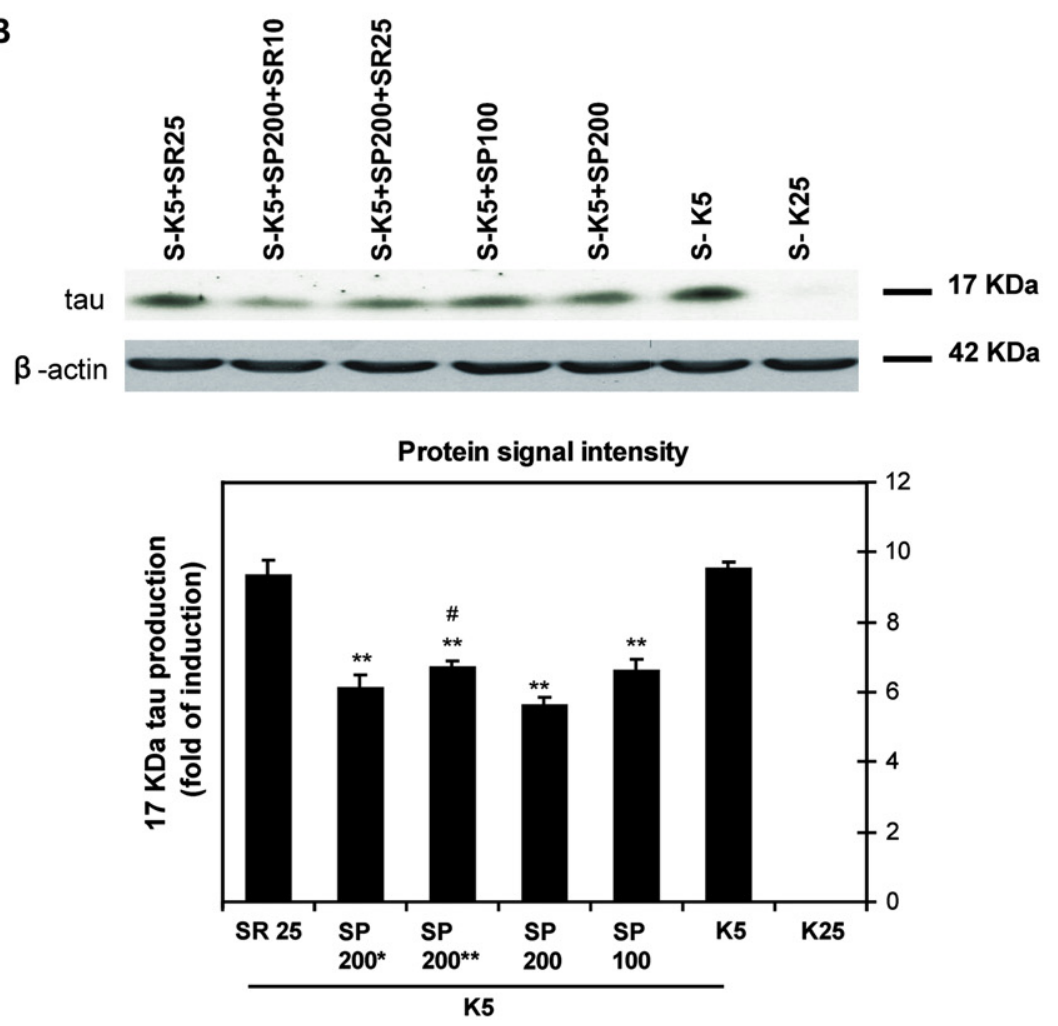

Fig. 6. Action of SP on the calpain-1 activity during the CGCs death induced by potassium and serum deprivation. At 6 DIV, CGCs were maintained for $48 \mathrm{~h}$ in S-K25 or subjected to S-K5 alone or in the presence of SP at $200 \mathrm{nM}$. (A) Western blot analysis of active calpain-1 content employing an antibody that recognized the $58 \mathrm{kDa}$ active form of calpain-1. $\beta$-actin immunoblot was used as loading control. (B) CGCs were analyzed by Western blotting using the mAb tau- 1 antibody recognizing the $17 \mathrm{kDa}$ fragment of tau protein, released during the CGCs death induced by S-K5. At 6 DIV, CGCs were maintained for $48 \mathrm{~h}$ in S-K25 or subjected to S-K5 alone or in the presence of SP at different concentrations (100 and $200 \mathrm{nM}$ ). The action of the NK1 receptor antagonist SR140,333 (SR) was evaluated treating the CGCs in S-K5 conditions with the antagonist alone $(25 \mathrm{nM})$, or in the presence of SP $(200 \mathrm{nM})$ at different concentrations, $10 \mathrm{nM}$ (SP $200 *)$ and $25 \mathrm{nM}$ (SP $200^{* *}$ ). Quantitative analysis of calpain-1 activity and $17 \mathrm{kDa}$ tau fragment production is depicted next to and below the respective blots and was determined by band densitometry analysis. The ratio of the band intensities was calculated considering the values found in K25 treated cells as 1. Data represent means $( \pm$ SEM) from 3 duplicate experiments. Statistically significant differences were calculated by one-way analysis of variance (ANOVA) for repeated measures followed by Tukey's test for multiple comparisons. (**p $<0.01$ versus K5; \#p $<0.05$ versus SP200).

Yoshioka, 1993; Pennefather et al., 2004). In the CNS, TK receptors have been implicated in various behavioral responses and in regulating neuronal survival and degeneration (Quartara and Maggi, 1998). Although previous studies indicated the expression of TK receptors in rat cerebellum (Otsuka and Yoshioka, 1993), direct evidence for the presence of such receptors in CGCs has been reported only for NK2 and NK3 receptors (Pieri et al., 2005). In fact, we have recently demonstrated that NKA and NKB can increase glutamate toxicity in CGCs, while SP did not affect the same response, indicating the involvement of NK2 and NK3 receptors in the neuronal excitability (Severini et al., 2003; Pieri et al., 2005). On the contrary, several studies have suggested an involvement of NK1 receptors in neuronal development/survival both in vitro 
A

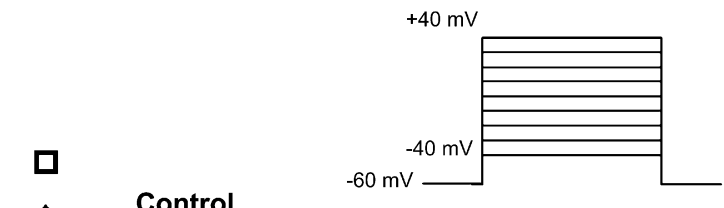

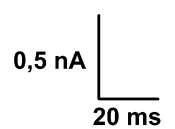

C

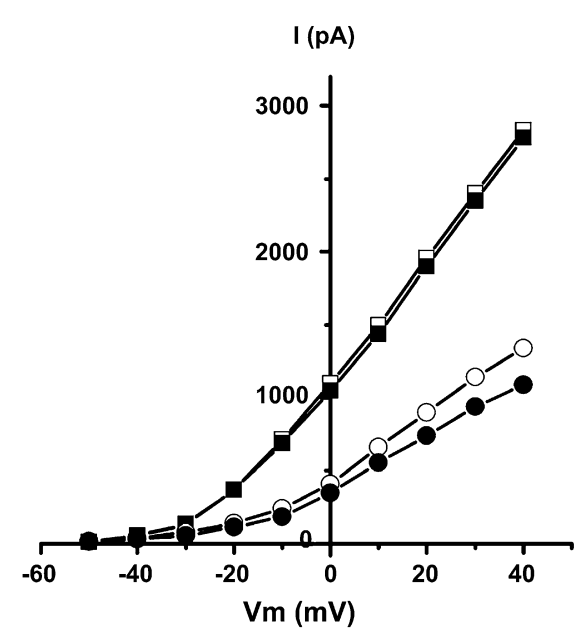

D

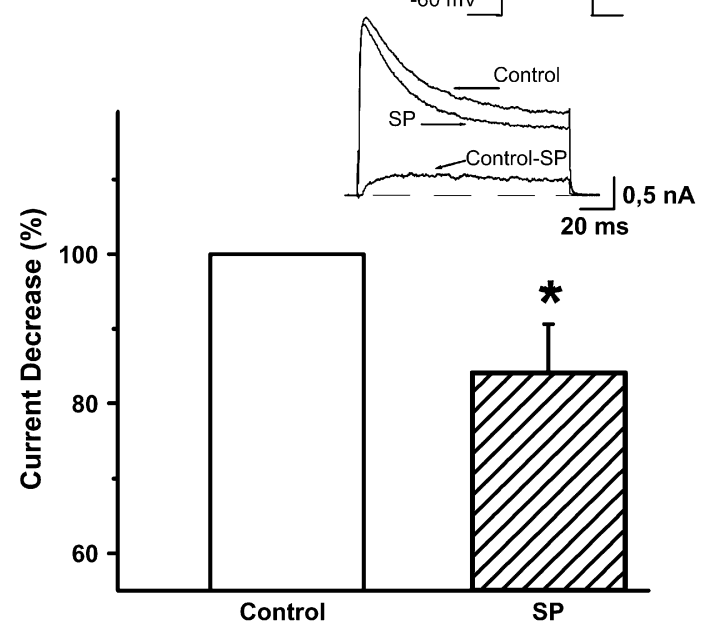

Fig. 7. Effect of SP on the voltage-dependent transient and delayed toward $\mathrm{K}^{+}$currents in cultured rat CGCs. (A) Outward $\mathrm{K}^{+}$currents were evoked by $200 \mathrm{~ms}$ depolarization pulses from $-40 \mathrm{mV}$ to $+40 \mathrm{mV}$, step $10 \mathrm{mV}$, from a holding potential of $-60 \mathrm{mV}$. The CGC was 9 days old in culture. (B) Effect of SP (200 nM) after $20 \mathrm{~s}$ of perfusion on outward $\mathrm{K}^{+}$currents in the same cell shown in A. (C) I/V curves of the granule cell shown in A, of the peak current before and after $30 \mathrm{~s}$ of SP perfusion ( $)$ and of the late component before ( $\bigcirc$ ) and after $20 \mathrm{~s}$ of SP perfusion ( $(\mathrm{)})$. (D) Histogram of the late component $\mathrm{K}^{+}$current decrease in $n=20$ cerebellar granule cells 8-10 days old in culture. The values of the current amplitudes were related to a depolarization to $+40 \mathrm{mV}$ from a holding potential of $-60 \mathrm{mV}$ (protocol and example traces are shown in inset). The decrease is statistically significant $(p<0.05)$.

and in vivo, where SP exerts a "trophic" action (Quartara and Maggi, 1998). Moreover, a trophic role of the NK1 receptors activation has been proposed, especially during the development period of CNS (Taoka et al., 1996; Hokfelt et al., 2000), in agreement with previous data reporting the neurotrophic action exerted by SP in cultured neurons (Whitty et al., 1993; Salthun-Lassalle et al., 2005). These observations have led to speculate that SP can physiologically protect the neurons from death and that its effect may be pathogenically relevant in the neurodegenerative processes (Raffa, 1998). In the current study, we have demonstrated that also in CGCs, treatment with SP and other NK1 receptor agonists moderately protected these neurons from death induced by serum and $\mathrm{K}^{+}$ deprivation, and that this action is mediated by the presence of NK1 receptors. Indeed, in CGCs we have demonstrated by
RT-PCR the presence of SP high affinity NK1 receptor transcript, and by Western blotting the expression of the same receptor. In addition, the presence and membrane localization of NK1 receptor protein was confirmed by immunocytochemistry in a subpopulation corresponding to $47 \%$ of entire culture. It is tempting to speculate that cultured, and possibly in vivo developed CGCs are constituted by two distinct populations: one, accounting to approximately $50 \%$ is endowed with NK2 and NK3 receptors exerting a glutamate sensitizing activity (Severini et al., 2003), while another of the approximately the same size possess NK1 receptors transducing an antiapoptotic message reported in this paper.

Numerous evidences indicated that MAPK/Erk 1/2 isoforms are activated by SP is several cell types (Vaudry et al., 2002) and recently, a protective action of SP against apoptosis via 
MAP/Erk 1/2 pathways has been proposed in rat spiral ganglion neurons (Lallemend et al., 2003). In the cellular system used in this study we have verified, by Western blot analyses, the up-regulation of MAPK-Erk 1/2 pathways since treatment with SP positively modulated the Erk1/2 phosphorylation, significantly reduced in K5 conditions, as compared with the K25 control sample. Moreover, treatment with a selective NK1 receptor antagonist significantly reduced SPmediated Erk1/2 phosphorylation. Confirming the specific involvement of MAPK-Erk 1/2 pathways in the SP neuroprotection, UO126 treatment reduced SP-mediated Erk1/2 phosphorylation and completely prevented the neuroprotective effect exerted by SP as reported by neuronal viability data.

Interestingly, we also demonstrated that activation of MAPK-Erk1/2 kinase pathways was not the exclusive way to protect CGCs from S-K5 cell death. In fact, using an antibody against phospho-Akt we observed in SP-treated CGCs, a significant increased level of the active form of this enzyme known to be involved in promoting the survival of different cell types and to be significantly down-regulated in S-K5 CGCs (Finkbeiner, 2000). Indeed, it has been reported that the survival of mature CGCs after serum and $\mathrm{K}^{+}$withdrawal can be maintained by several different survival factors, all converging on the activation of the Akt (Vaillant et al., 1999; Kumari et al., 2001).

The data reported in this work corroborate our findings that SP, rescuing CGCs from cell death via the Akt survival pathway, may act as a physiological regulator of cell survival for CGCs.

Unexpectedly, although SP in other systems has been shown to inhibit active caspase-3, addition of SP and other NK1 receptor agonists to cultured CGCs provided neuroprotection of these neurons from death without affecting caspase-3 activation.

To our knowledge, this is the first study reporting a mechanism of neuroprotection exerted by SP that acts through a pathway other than active caspase-3, suggesting an alternative mechanism of protection that can occur either downstream or independently from caspase-3 activation in K5-injured CGCs. Thus, we established by Western blot analysis that SP attenuated and delayed apoptosis induction through inhibition of calpain-1, a cystein protease that exists as pro-enzyme in resting cells, and known to be activated in this paradigm of neuronal death (Canu et al., 1998; Neumar et al., 2003). Indeed, using an antibody that recognized $58 \mathrm{kDa}$ active form of calpain 1 , we showed that active calpain levels were moderately but significantly reduced by treatment with SP compared with K5 untreated controls. Moreover, in accordance with previous results demonstrating the reduction of the $17 \mathrm{kDa}$ tau band in the presence of anti-apoptotic reagents (Canu et al., 1998), we showed that SP was able, dose-dependently, to reduce calpain-mediated tau cleavage, as demonstrated by the reduction of the diagnostic $17 \mathrm{kDa}$ fragment released in S-K5 conditions. The importance of calpain as molecular target, able to interfere in neuronal death/survival, was demonstrated by the neuroprotective effect exerted by selective calpain inhibitors in CGCs (Nath et al., 1996; Verdaguer et al., 2005). Thus, SP promotes the survival of S-K5 CGCs at nanomolar concentrations by inhibiting calpain-1 activity but without affecting caspase 3 activity, throughout an upregulation of phospho-Akt levels.
This result is in accordance with recent data demonstrating, in such neuronal death paradigm, an analogous mechanism of action exerted by CEP-1347, an inhibitor of JNK signaling (Harris et al., 2002). Moreover, as demonstrated in this model by Verdaguer et al. (2005), death programme is further complicated by cross-talk between calpain and caspases proteolytic system. Calpain can modulate the caspases, but calpain activity itself is in turn regulated by caspases, through depletion of endogenous calpain inhibitor calpastatin (Neumar et al., 2003). In addition, apoptotic and necrotic processes coexist in our paradigm of neuronal death and mutual transition between them has been reported (Atlante et al., 2003).

As generally accepted, $\mathrm{K}^{+}$channels have a key role in the regulation of neuronal excitability, setting both the resting membrane potential, the action potential duration and the neurotransmitter release (Meir et al., 1999). The opening of the $\mathrm{K}^{+}$ channels and the consequent efflux of $\mathrm{K}^{+}$ions play a critical role in the control of neuronal death/survival. Commonly, an enhancement of the delayed rectifier $\mathrm{K}^{+}$currents (Ik) may induce cell death, as demonstrated by the effect exerted by serum deprivation, $N$-methyl-D-aspartate, staurosporine or ceramide treatment in the apoptosis induction in neurons ( $\mathrm{Yu}$ et al., 1999). Indeed, the activation of the potassium currents is responsible for intracellular $\mathrm{K}^{+}$loss, which may consequently cause apoptosis (Bortner and Cidlowski, 1999). In contrast, substances like PACAP, able to reduce $\mathrm{K}^{+}$outflow in CGCs, may promote survival, confirming the evidence that the suppression of the normal $\mathrm{K}^{+}$electrochemical gradient can attenuate several stages of the cell-death pathway (Mei et al., 2004). Thus, the inhibitory effect of SP on the Ik currents amplitude in CGCs that we reported, suggests that the SP neuroprotective action can be accounted, at least in part, by inhibition of the $\mathrm{K}^{+}$currents, which in turn prevents a decrease in cytoplasmatic potassium concentration.

In conclusion, the present work has provided clues for the possible signalling pathways that are activated by SP to execute its protective function in CGCs. We have demonstrated that SP prevents cell death in S-K5 CGCs cultures by upregulating Akt and ERK1/2 phosphorylation through a pathway that does not involve active caspase 3 , but interferes with calpain activity, suggesting a mechanism different from that reported in other systems for SP neuroprotection. Furthermore, the non-ubiquitary distribution of NK1 receptors in CGCs suggests that the subpopulation endowed with NK1 receptors can transduce an antiapoptotic message, while NK2 and NK3 receptors, exerting a glutamate sensitizing activity, play no role in neuroprotection.

In addition, for the first time we have demonstrated that SP can modulate the $\mathrm{I}_{\mathrm{k}}$, showing, in this contest, a striking analogy in the mechanism of action with PACAP, another physiological neuropeptide active in the CNS.

Finally, because SP, neuroptrophic/neuroprotective agent in many biological systems, was previously demonstrated to be present in the rat cerebellum and, more specifically in the glial cells (Barbato et al., 2005), the question whether SP may act as a physiological regulator of cell survival for CGCs in vivo remains to be established. 


\section{Acknowledgements}

We would like to thank Dr. Roberta Possenti for her comments on the manuscript. This work was partially supported by Regione Lazio funding for "Sviluppo della ricerca sul cervello" and by Neurodegenerativo 2004 ex art 56; 533 F/B/1 to N.Canu.

\section{Appendix A. Supplementary data}

Supplementary data associated with this article can be found, in the online version, at 10.1016/j.neuropharm.2007.01.020.

\section{References}

Armstrong, R.C., Aja, T.J., Hoang, K.D., Gaur, S., Gaur, S., Bai, X., Alnemri, E.S., Litwack, G., Karanewsky, D.S., Fritz, L.C., Tomaselli, K.J., 1997. Activation of the CED3/ICE-related protease CPP32 in cerebellar granule neurons undergoing apoptosis but not necrosis. J. Neurosci. 17, 553-562.

Atlante, A., Bobba, A., Calissano, P., Passerella, S., Marra, E., 2003. The apoptosis/necrosis transition in cerebellar granule cells depends on the mutual relationship of the antioxidant and the proteolytic system which regulate ROS production and cytochrome $\mathrm{c}$ release en route to death. J. Neurochem. 84, 960-971.

Barbato, C., Ciotti, M.T., Serafino, A., Severini, C., Calissano, P., 2005. Tachykinin neuropeptides in cerebellar granule neurons: an immunocytochemical study. Eur. J. Histochem. 49, 87-92.

Bortner, C.D., Cidlowski, J.A., 1999. Caspase independent/dependent regulation of $\mathrm{K}(+)$, cell shrinkage, and mitochondrial membrane potential during lymphocyte apoptosis. J. Biol. Chem. 274, 21953-21962.

Canu, N., Calissano, P., 2003. In vitro cultured neurons for molecular studies correlating apoptosis with events related to Alzheimer disease. Cerebellum 2, 270-278.

Canu, N., Dus, L., Barbato, C., Ciotti, M.T., Brancolini, C., Rinaldi, A.M., Novak, M., Cattaneo, A., Bradbury, A., Calissano, P., 1998. Tau cleavage and dephosphorylation in cerebellar granule neurons undergoing apoptosis. J. Neurosci. 18, 7061-7074.

Canu, N., Barbato, C., Ciotti, M.T., Serafino, A., Dus, L., Calissano, P., 2000. Proteasome involvement and accumulation of ubiquitinated proteins in cerebellar granule neurons undergoing apoptosis. J. Neurosci. 20, 589-599.

Chaib-Oukadour, I., Gil, C., Aguilera, J., 2004. The C-terminal domain of the heavy chain of tetanus toxin rescues cerebellar granule neurones from apoptotic death: involvement of phosphatidylinositol 3-kinase and mitogenactivated protein kinase pathways. J. Neurochem. 90, 1227-1236.

Chomczynski, P., Sacchi, N., 1987. Single-step method of RNA isolation by acid guanidinium thiocyanate-phenol-chloroform extraction. Anal. Biochem. 162, 156-159.

D’Mello, S.R., Galli, C., Ciotti, T., Calissano, P., 1993. Induction of apoptosis in cerebellar granule neurons by low potassium: inhibition of death by insulin-like growth factor I and cAMP. Proc. Natl. Acad. Sci. U.S.A. 90, 10989-10993.

Finkbeiner, S., 2000. CREB couples neurotrophin signals to survival messages. Neuron 25, 11-14.

Galli, C., Meucci, O., Scorziello, A., Werge, T.M., Calissano, P., Schettini, G., 1995. Apoptosis in cerebellar granule cells is blocked by high $\mathrm{KCl}$, forskolin, and IGF-1 through distinct mechanisms of action: the involvement of intracellular calcium and RNA synthesis. J. Neurosci. 15, 1172-1179.

Gallo, V., Giovannini, C., Levi, G., 1990. Modulation of non- $N$-methyl-Daspartate receptors in cultured cerebellar granule cells. J. Neurochem. 54, 1619-1625.

Gunn-Moore, F.J., Williams, A.G., Toms, N.J., Tavare, J.M., 1997. Activation of mitogen-activated protein kinase and p70S6 kinase is not correlated with cerebellar granule cell survival. Biochem. J. 324, 365-369.
Harris, C., Maroney, A.C., Johnson Jr., E.M., 2002. Identification of JNKdependent and -independent components of cerebellar granule neuron apoptosis. J. Neurochem. 83, 992-1001.

Hokfelt, T., Broberger, C., Xu, Z.Q., Sergeyev, V., Ubink, R., Diez, M., 2000 Neuropeptides: an overview. Neuropharmacology 39, 1337-1356.

Hu, C.L., Liu, Z., Gao, Z.Y., Zhang, Z.H., Mei, Y.A., 2005. 2-iodomelatonin prevents apoptosis of cerebellar granule neurons via inhibition of A-type transient outward K+ currents. J. Pineal. Res. 38, 53-61.

Kumari, S., Liu, X., Nguyen, T., Zhang, X., D’Mello, S.R., 2001. Distinct phosphorylation patterns underlie Akt activation by different survival factors in neurons. Brain Res. Mol. Brain Res. 96, 157-162.

Lallemend, F., Lefebvre, P.P., Hans, G., Rigo, J.M., Van de Water, T.R., Moonen, G., Malgrange, B., 2003. Substance P protects spiral ganglion neurons from apoptosis via PKC-Ca2+-MAPK/ERK pathways. J. Neurochem. 87, 508-521.

Lazebnik, Y.A., Kaufmann, S.H., Desnoyers, S., Poirier, G.G., Earnshaw, W.C., 1994. Cleavage of poly(ADP-ribose) polymerase by a proteinase with properties like ICE. Nature 37, 346-347.

Levi, G., Aloisi, F., Ciotti, M.T., Gallo, V., 1984. Autoradiographic localization and depolarization-induced release of acidic amino acids in differentiating cerebellar granule cell cultures. Brain Res. 290, 77-86.

Mei, Y.A., Vaudry, D., Basille, M., Castel, H., Fournier, A., Vaudry, H., Gonzalez, B.J., 2004. PACAP inhibits delayed rectifier potassium current via a cAMP/PKA transduction pathway: evidence for the involvement of $I_{k}$ in the anti-apoptotic action of PACAP. Eur. J. Neurosci. 19, 1446-1458.

Meir, A., Ginsburg, S., Butkevich, A., Kachalsky, S.G., Kaiserman, I., Ahdut, R., Demirgoren, S., Rahamimoff, R., 1999. Ion channels in presynaptic nerve terminals and control of transmitter release. Physiol. Rev. 79, 1019-1088.

Nath, R., Raser, K.J., Stafford, D., Hajimohammadreza, I., Posner, A., Allen, H., Talanian, R.V., Yuen, P., Gilbertsen, R.B., Wang, K.K., 1996. Non-erythroid alpha-spectrin breakdown by calpain and interleukin 1 beta-convertingenzyme-like protease(s) in apoptotic cells: contributory roles of both protease families in neuronal apoptosis. Biochem. J. 319, 683-690.

Neumar, R.W., Xu, Y.A., Gada, H., Guttmann, R.P., Siman, R., 2003. Crosstalk between calpain and caspase proteolytic systems during neuronal apoptosis. J. Biol. Chem. 278, 14162-14167.

Otsuka, M., Yoshioka, K., 1993. Neurotransmitter functions of mammalian tachykinins. Physiol. Rev. 73, 229-308.

Pennefather, J.N., Lecci, A., Candenas, M.L., Patak, E., Pinto, F.M., Maggi, C.A., 2004. Tachykinins and tachykinin receptors: a growing family. Life Sci. 74, 1445-1463.

Pieri, M., Severini, C., Amadoro, G., Carunchio, I., Barbato, C., Ciotti, M.T., Zona, C., 2005. AMPA receptors are modulated by tachykinins in rat cerebellum neurons. J. Neurophysiol. 94, 2484-2490.

Quartara, L., Maggi, C.A., 1998. The tachykinin NK1 receptor. Part II: Distribution and pathophysiological roles. Neuropeptides 32, 1-49.

Raffa, R.B., 1998. Possible role(s) of neurokinins in CNS development and neurodegenerative or other disorders. Neurosci. Bioehav. Rev. 22, 789-813.

Rosen, L.B., Ginty, D.D., Weber, M.J., Greenberg, M.E., 1994. Membrane depolarization and calcium influx stimulate MEK and MAP kinase via activation of Ras. Neuron 12, 1207-1221.

Salthun-Lassalle, B., Traver, S., Hirsch, E.C., Michel, P.P., 2005. Substance P, neurokinins $\mathrm{A}$ and $\mathrm{B}$, and synthetic tachykinin peptides protect mesencephalic dopaminergic neurons in culture via an activity-dependent mechanism. Mol. Pharmacol. 68, 1214-1224.

Severini, C., Improta, G., Falconieri-Erspamer, G., Salvadori, S., Erspamer, V., 2002. The tachykinin peptide family. Pharmacol. Rev. 54, 285-322.

Severini, C., Ciotti, M.T., Mercanti, D., Barbato, C., Calissano, P., 2003. A tachykinin-like factor increases glutamate toxicity in rat cerebellar granule cells. Neuropharmacology 44, 117-124.

Shieh, C.C., Coghlan, M., Sullivan, J.P., Gopalakrishnan, M., 2000. Potassium channels: molecular defects, diseases, and therapeutic opportunities. Pharmacol. Rev. 52, 557-594.

Taoka, M., Song, S.Y., Kubota, M., Minegishi, A., Yamakuni, T., Konishi, S., 1996. Increased level of neurokinin-1 tachykinin receptor gene expression during early postnatal development of rat brain. Neuroscience 74, 845-853.

Vaillant, A.R., Mazzoni, I., Tudan, C., Boudreau, M., Kaplan, D.R., Miller, F.D., 1999. Depolarization and neurotrophins converge on the 
phosphatidylinositol 3-kinase-Akt pathway to synergistically regulate neuronal survival. J. Cell Biol. 146, 955-966.

Vaudry, D., Stork, P.J., Lazarovici, P., Eiden, L.E., 2002. Signaling pathways for PC12 cell differentiation: making the right connections. Science 296, $1648-1649$.

Verdaguer, E., Alvira, D., Jimenez, A., Rimbau, V., Camins, A., Pallas, M., 2005. Inhibition of the cdk5/MEF2 pathway is involved in the antiapoptotic properties of calpain inhibitors in cerebellar neurons. Br. J. Pharmacol. 145, 1103-1111.

Volontè, C., Ciotti, M.T., Battistini, L., 1994. Development of a method for measuring cell number: application to CNS primary neuronal cultures. Cytometry 17, 274-276.

Whitty, C.J., Kapatos, G., Bannon, M.J., 1993. Neurotrophic effects of substance $\mathrm{P}$ on hippocampal neurons in vitro. Neurosci. Lett. 164, 141-144.
Yu, S.P., 2003. Regulation and critical role of potassium homeostasis in apoptosis. Prog. Neurobiol. 70, 363-386.

Yu, S.P., Yeh, C.H., Gottron, F., Wang, X., Grabb, M.C., Choi, D.W., 1999. Role of the outward delayed rectifier $\mathrm{K}+$ current in ceramide-induced caspase activation and apoptosis in cultured cortical neurons. J. Neurochem. 73, 933-941.

Zhu, D., Jiang, X., Wu, X., Tian, F., Mearow, K., Lipsky, R.H., Marini, A.M., 2004. Inhibition of protein kinase $C$ promotes neuronal survival in low potassium through an Akt-dependent pathway. Neurotox. Res. 6, 281-289.

Zona, C., Ragazzino, D., Ciotti, M.T., Mercanti, D., Avoli, M., Brancati, A., Calissano, P., 1993. Sodium, calcium and late potassium currents are reduced in cerebellar granule cells cultured in the presence of a protein complex conferring resistance to excitatory amino acids. Eur. J. Neurosci. $5,1479-1484$. 